\title{
Irreversible modifications of chromatin and the nuclear lamina: A review inside the nuclear origin of Alzheimer's disease
}

\author{
Laura Gil'1", Gabriela Capdeville ${ }^{2 * \pi}$, Ildefonso Rodríguez-Leyva ${ }^{3}$, Sandra A. Niño ${ }^{4}$, and \\ María E. Jiménez-Capdeville 4
}

${ }^{1}$ Departamento de Genética, Escuela de Medicina, Universidad "Alfonso X el Sabio", Madrid, España; '2Escuela de Medicina, Universidad Panamericana, Mexico City; ${ }^{3}$ Servicio de Neurología, Hospital Central "Ignacio Morones Prieto", San Luis Potosi; ${ }^{4}$ Departamento de Bioquímica, Facultad de Medicina, Universidad Autónoma de San Luis Potosí, San Luis Potosí, Mexico

"These authors contributed equally in this study.

\begin{abstract}
Dementia is a public health problem with an extraordinary increase in recent years. Alzheimer's disease (AD) is the most common cause of dementia. This disease has been considered a consequence of cytoplasmic and extracellular accumulations of Tau protein and $\beta$ - amyloid, respectively. Nevertheless, a nuclear origin of AD has recently emerged. Both Tau protein and the nuclear lamin protect the nuclear and chromatin organization for proper gene expression throughout neuronal life. Accumulation of DNA damage, mainly as a result of aging, drives post-mitotic neurons to initiate DNA repair by entering the cell cycle. The complexity of the nucleus-cytoskeleton prevents neurons from dividing and condemns them to a state of hyperdiploidy ending in neuronal death, after transiently prolonging their life. In $A D$, hippocampal neurons survive their fatal fate by triggering an aberrant structural and functional transformation of the nucleus. Lamin A expression and Tau protein transfer to the cytoplasm results in loss of the protector role of nuclear Tau and the subsequent global chromatin disorganization. Therefore, the cytoplasmic Tau protein accumulations that characterize AD are consequence of the attempted neuronal repair. Alzheimer's neurons with unstructured nuclei and aberrant cytoskeletons manage to survive by sacrificing their plasticity, which inexorably leads to dementia.
\end{abstract}

Key words: Alzheimer's disease. Tau protein. Amyloid Beta. Chromatin. Lamin A. Neuronal nucleus.

\section{Modificaciones irreversibles de la cromatina y la lámina nuclear: una revisión sobre el origen nuclear de la enfermedad de Alzheimer}

\section{Resumen}

La demencia es un problema de salud pública que se ha incrementado a un ritmo desmedido. La enfermedad de Alzheimer (EA) es la causa más frecuente de demencia, considerada como consecuencia de acúmulos citoplasmáticos y extracelulares de proteína Tau y ßamiloide, respectivamente. Sin embargo, recientemente ha emergido un origen nuclear. La proteína Tau y la lámina nuclear resguardan la organización nuclear y de la cromatina necesarias para la correcta expresión génica. El daño al DNA asociado al envejecimiento orilla a las neuronas posmitóticas a iniciar su reparación entrando en ciclo celular. La complejidad del núcleo-citoesqueleto impide su división y permanecen en estado de hiperdiploidía que, aun alargando

Correspondence:

*María E. Jiménez-Capdeville

E-mail: mejimenez@uaslp.mx
Available online: $25-05-2021$ Rev Mex Neuroci. 2021;22(3):124-131 www.revmexneurociencia.com 1665-5044/ @ 2021 Academia Mexicana de Neurología A.C. Published by Permanyer. This is an open access article under the CC BY-NC-ND license (http://creativecommons.org/licenses/by-nc-nd/4.0/). 
la vida neuronal, culmina en su muerte. No obstante, en EA las neuronas del hipocampo sobreviven desencadenando una aberrante transformación estructural y funcional del núcleo a través de la expresión de lámina $A$ y el trasvase al citoplasma de la proteína Tau, lo que conlleva la pérdida del rol protector de Tau nuclear y la desorganización cromatínica global. Así, los agregados de proteína Tau citoplasmática característicos de EA son consecuencia del intento de reparación neuronal. Estas neuronas con núcleos desestructurados y citoesqueletos aberrantes sobreviven sacrificando su plasticidad, lo que conduce inexorablemente a la demencia.

Palabras clave: Enfermedad de Alzheimer. Proteína Tau. Beta amiloide. Cromatina. Lámina A. Núcleo neuronal.

\section{Introduction}

An estimated 50 million people worldwide have dementia, with Alzheimer's disease (AD) representing 70$80 \%$ of cases. ${ }^{1}$ It is expected that by the year 2050,150 million people globally will suffer from some form of dementia ${ }^{1}$.

In Mexico, the panorama is not very different. We have a rapidly aging population which is transforming the triangular shape of the population pyramid representing the predominance of young people over the elderly, to a rectangular one made up of the same number of young people as seniors; however, the longterm trend is a complete transformation into an inverted pyramid. The prevalence of $A D$ in Mexico is $7.3 \%$ and has an incidence of 27.3 (1000 person/year). It is estimated that by the year 2050, the number of Mexicans with $\mathrm{AD}$ will be $>3.5$ million?

Dementia is a physical, social, and emotional problem and one of the most important causes of disability and dependency among older adults ${ }^{1}$. Furthermore, it represents a substantial economic impact. For these reasons, dementia is considered a priority for public health in Mexico and it is also considered a global emergency. Today, more people live with dementia than those who can be cared for by the rest of the population.

At present, $A D$ diagnosis is based on clinical data ${ }^{3}$. Positron emission tomography scans for $A \beta$ ( $\beta$-amyloid peptide) and Tau protein are expensive diagnostic tools, only available in some highly specialized centers. Nevertheless, in recent years, three core cerebrospinal fluid biomarkers have been identified: A $\beta 42$ (42-aminoacid form of $A \beta$ ), T-tau (total Tau), and P-tau (phosphorylated tau). These biomarkers have reached a specificity and sensitivity ranging between 85 and $90 \%$ for the diagnosis of $A D$ and also for the stage of mild cognitive impairment due to AD. Although only through postmortem histopathological findings, it is possible to reach a definitive diagnosis, other emerging biomarkers such as presence of P-Tau in blood, skin, and oral mucosa ${ }^{4-6}$ are promising tools.
At present, $A D$ treatment is merely symptomatic. Pharmacological treatment involves acetylcholinesterase inhibitors and $\mathrm{N}$-methyl $\mathrm{d}$-aspartate receptor antagonists. They contribute minimally to early stages of disease and they do slow the progression of $A D$ in later stages and provide some symptomatic relief but do not achieve a definite cure ${ }^{7}$. Considering the high prevalence of the disease, it is necessary to progress in our understanding of its pathogenesis so that in the future, an earlier diagnosis can be achieved and eventually, a progression modifier treatment could be offered to patients.

\section{Current knowledge on the pathogenesis of $A D$}

Based on the histopathological characteristics of the disease, amyloid plaques and neurofibrillary tangles presented by all patients who die from $A D$, the hypothesis of "the amyloid cascade" has been formulated as pathogenesis of the disease for almost 30 years $^{8}$. This theory proposes that the amyloid precursor protein (APP), an integral membrane protein, is abnormally processed to beta-amyloid (AB), which forms $A \beta$ plaques that cause neuronal dysfunction and death. Likewise, the toxic concentrations of beta-amyloid favor different conformational changes in the Tau protein, leading to the formation of neurofibrillary tangles, which culminate in structural and functional alterations of neurons (Fig. 1). It has been the most accepted theory, since mutations of several genes such APP and some enzymes that process this protein (presenilins, PSEN1 and PSEN2) are causes of the early-onset familial form, which accounts for $1 \%$ of $A D$ cases $^{9}$. Furthermore, sleep affects $A \beta$ accumulation and clearance through the glymphatic system. For both animal and human models, it has been observed that sleep deprivation causes the augmentation of soluble $A \beta^{10}$. Nevertheless, a significant limitation of this hypothesis is the fact that the presence of amyloid pathology is not always accompanied by dementia ${ }^{11}$. In fact, amyloid deposition 


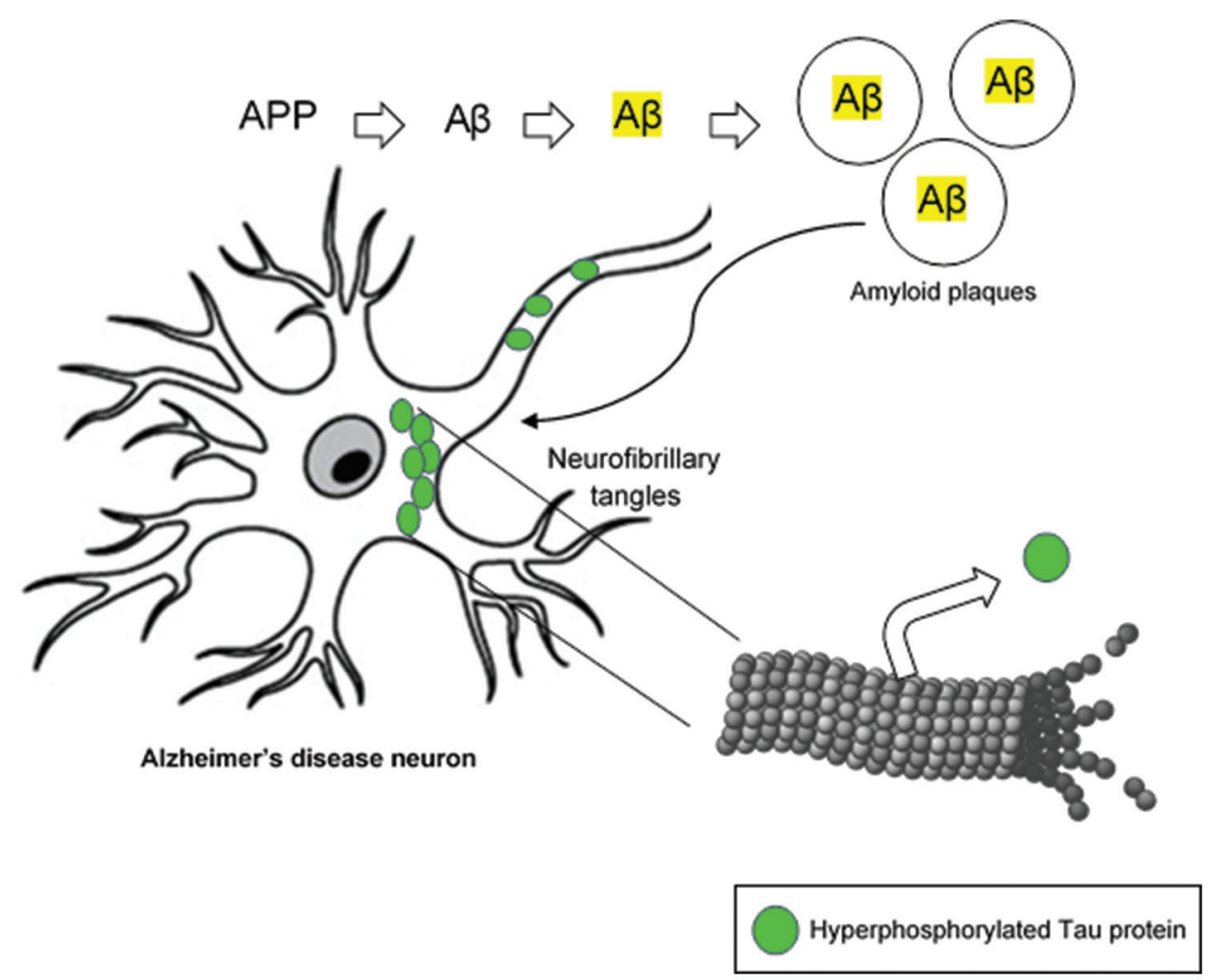

Figure 1. Schematic representation of the amyloid cascade hypothesis. Alzheimer's disease would start by the abnormal processing of the amyloid precursor protein to $\beta$-amyloid, whose aggregation constitutes amyloid plaques. These abnormal structures would activate Tau protein hyperphosphorylation, its detachment from microtubule and subsequent building neurofibrillary tangles.

was present approximately in $25-30 \%$ of cognitively intact individuals in their eighth decade ${ }^{12}$.

On the other hand, the universal finding of hyperphosphorylated Tau protein in neurofibrillary tangles and its high correlation with the degree of cognitive deficit in patients has tilted the balance toward the dysfunction of this protein as a causal disease agent ${ }^{13}$, However, a group of progressive neurodegenerative diseases called tauopathies" that present the pathological conformation of Tau has been documented ${ }^{14}$. Therefore, despite being part of $A D$ pathognomonic findings, hyperphosphorylated Tau was ruled out as a specific causative $A D$ factor, due to its presence in other neurodegenerative diseases (Fig. 1).

\section{Spread of proteinopathies}

Most neurodegenerative diseases, including $A D$, are characterized by the aggregation of misfolded proteins in different brain regions, which follow a specific pattern for each disease. The presence of this phenomenon, similar to transmissible spongiform encephalopathies, whose causal agent is transforming the conformation of a protein, pointed out to the folding process and functionality of proteins as a cause of neurodegenerative diseases ${ }^{15}$.

To understand this theory, it would help to remember that the sequence of amino acids conforming the primary structure of proteins contains the folding information into a tertiary structure, which determines their function. The correct protein folding is crucial and several cellular mechanisms avoid abnormal folding. However, under certain post-translational modifications, energy deficit, or alterations of protein degradation pathways, proteins may fold in an alternative and dysfunctional tridimensional shape. It is proposed that neurons assemble these dysfunctional proteins into protein aggregate to focus their energy expenditure in other essential processes; this generates proteostasis alterations with an imbalance between protein synthesis and turnover. Due to the low-energy configuration that misfolded proteins acquire, abnormal folding of the rest 


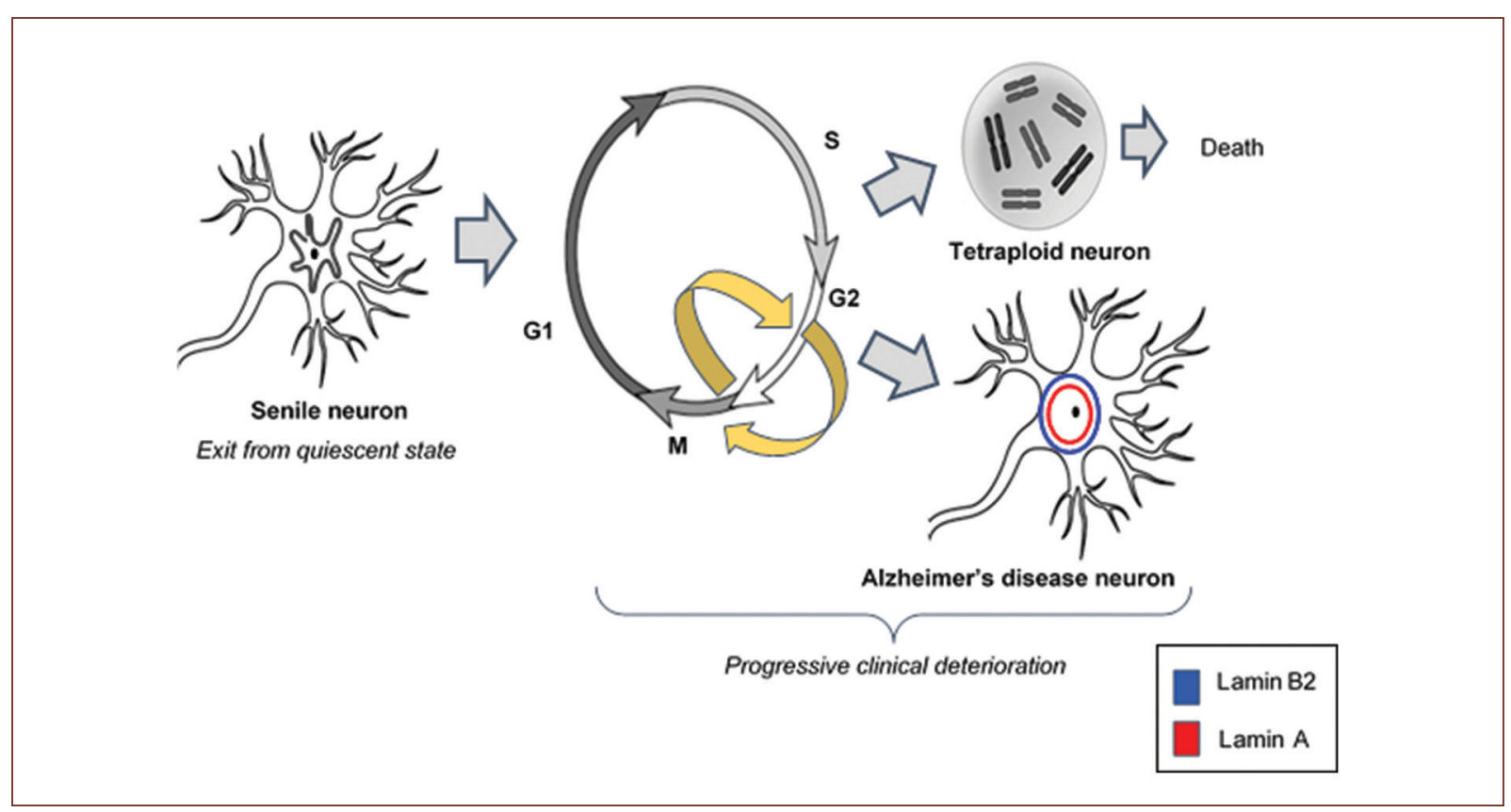

Figure 2. Aberrant cell cycle reentry. Cell cycle reentry by previously quiescent post-mitotic hippocampal neurons is a mechanism to repair DNA damage. Neurons with duplicated genetic material (hyperdiploid neurons), progressively die throughout Alzheimer's disease. Neurons that undergo nucleus-skeleton changes survive for years with synaptic dysfunction. These important transformations lead to progressive cognitive deficit.

of the proteins is favored, which "propagates" proteinopathy. This process is similar to the behavior of prions and has been demonstrated in the main neurodegenerative diseases ${ }^{16}$.

\section{New horizons}

The different theories proposed about AD pathogenesis continue to leave many unanswered questions about its onset and the evolution of the disease. Although the formation of protein aggregates and their spreading have been widely demonstrated, the factors that trigger alterations of proteostasis leading to the proteinopathy are not fully elucidated yet.

In the late 1990s, neuronal modifications beyond the appearance of neurofibrillary tangles and amyloid plaques were envisaged. Normally, since neurons are terminally differentiated cells, they maintain their quiescent state throughout the whole postnatal life. However, degenerating neurons were surprisingly found to show signs and cell cycle markers of mitosis. It was demonstrated that they emerge from their quiescent state undergoing abnormal reentry into the cell cycle in the direction toward mitosis ${ }^{11}$. The neurons that initiate $A D$ express cyclin $B$ and nuclear proliferation antigen which allows them to replicate their genome, and thus initiate the cell cycle. The reason for this is an attempt to repair the accumulated DNA damage over the years, which would allow them to survive. However, the complexity of their cytoskeleton and other factors does not allow them to divide, becoming trapped before the mitosis phase (Fig. 2). Neurons that have duplicated their genetic material, becoming hyperdiploid neurons, start appearing in the $A D$ preclinical phase and progressively die throughout the disease ${ }^{17}$. This theory explains that advanced age is the most decisive risk factor for developing AD. At present, it is well demonstrated that aging per se affects the structure and functionality of nuclear chromati ${ }^{18}$, which is related to the accumulation of DNA damage. Aging associated DNA damage is closely related to $A D$ pathogenesis and also to the pathogenesis of cancer $^{19}$, which has led us to consider that these two diseases, with a high prevalence in senile subjects, could have the same origin: a molecular origin that involves irreversible chromatin changes (Fig. 2).

\section{Tau in the frontier between aging and $A D$}

In light of these antecedents, recent research has analyzed the changes taking place in neurons of the hippocampus during aging and their nuclear transformation in AD. The localization of phosphorylated Tau 
protein inside the neuronal nuclei is one of the crucial findings that have recently emerged. After being considered a cytosolic protein with an important function by stabilizing the microtubules, its essential role as a nuclear protein was demonstrated ${ }^{20}$.

First, it was observed that a phosphorylated form of Tau progressively accumulates in the neuronal nuclei during aging ${ }^{21}$. Second, it was documented that Tau is essential for the healthy aging of post-mitotic neurons of the hippocampus, protecting the genome, and stabilizing the heterochromatin. It achieves this by allowing the adequate compaction of chromatin to silence repetitive DNA sequences and to guarantee the genome regulation ${ }^{22}$. This ability agrees with its increased presence in neuronal nuclei of senile subjects since, as we mentioned earlier, aging per se results in accumulation of DNA damage.

At early AD stages, Tau gradually disappears from the nucleus, followed by its presence in the neuronal cytoplasm at later stages of the disease, forming neurofibrillary tangles, and it is also found in extracellular aggregates and neuritic plaques. Since Tau protein interacts with the DNA, stabilizing heterochromatin ${ }^{23}$, the exit of Tau from the nucleus involves chromatin instability and dysregulation of eu- and heterochromatin gene expression ${ }^{24}$. Furthermore, Tau accumulation impairs RNA translation ${ }^{25}$ and results in a pathological transformation of the nucleus-skeleton, characteristic of $A D$, involving global chromatin decondensation ${ }^{26}$.

Importantly, Tau exit from neuronal nuclei throughout $A D$ culminates in the loss of neuronal plasticity associated to the presence of neurofibrillary tangles. Thus, a series of events that generate the dysfunctional $A D$ neuron involve global decondensed chromatin ${ }^{27}$, activation of previously silenced gene sequences ${ }^{28}$, repression of genes characteristic of post-mitotic neurons and the reading of new genes ${ }^{29}$, alteration of nucleosomal transport, ${ }^{30}$ and alterations in the translation and transcription of several genes ${ }^{31}$.

\section{Initial proposals for AD as a laminopathy}

Considering that aging itself involves chromatin alterations, much has been speculated about the borderline between healthy aging and $A D$ onset. Over the past decade, based on research work carried out in a Drosophila melanogaster AD model, the nuclear lamin has been found to play an initial and decisive role in $A D$ onset ${ }^{27}$, even leading to propose that $A D$ would be an acquired laminopathy ${ }^{32}$. Although both aging and $A D$ are closely related to nuclear lamin dysfunction ${ }^{33}$, it was still unclear the decisive "challenge" that leads neurons to an irreversible nuclear transformation that culminates in neurodegeneration and dementia.

The nuclear lamin is a flexible polymer mesh. We could imagine it as a scaffold that contains a diffuse network inside and is surrounded on the periphery by a nuclear lamin. The nuclear lamin is anchored to the cytoskeleton and extends through the nucleoplasm. Its function is to give structure to the nucleus, as well as to regulate chromatin. Its main components are lamin A, lamin B1, lamin B2, and lamin $C^{19}$. Each of these proteins has independent mechanical properties ${ }^{33}$. Actually, one important $A \beta$ effect is fragmentation of lamin proteins. In vitro, nuclear lamina deformation and fragmentation are observed in $A \beta$-treated cells and may contribute to neuronal death ${ }^{34}$.

It is important to emphasize that neurons, unlike other cells in the human body, do not have lamin A in their nuclear lamin, which gives the nucleus-skeleton greater flexibility ${ }^{35-37}$. The close and complex relationship of nuclear lamin with chromatin modulates euchromatin and heterochromatin and safeguards the stability of the genome ${ }^{26}$.

\section{Alterations of the nuclear lamin among young, senile, and AD subjects}

Senile neurons possess a more complex nuclear lamin with less flexibility than young neurons. Nevertheless, the absence of lamin A allows them to maintain a certain degree of plasticity in the mechanical communication between their nucleus and cytoskeleton ${ }^{35,36}$.

Our research group set out to elucidate the pathogenesis of this disease by studying pyramidal neurons of the hippocampus (areas CA1 and CA3) from autopsies of human of healthy subjects of different ages (adults, senile), and AD subjects in different stages of disease (Braak I-VI). Our work demonstrated important changes of the nuclear lamin associated to AD progress that was described in detail in an already published work and outlined below ${ }^{26}$.

The nuclear lamin from AD hippocampal neurons has been observed to be abnormally complex ${ }^{35,36}$, but the most surprising finding made by our research group is that $A D$ neurons are the only ones that express lamin $A^{26}$. This suggests that the presence of lamin A confers greater rigidity to the core. The other nuclear lamin components, lamin B1 and B2, intertwine to construct a scaffold for heterochromatin. Lamin B1 is essential to assemble the different lamins that make up the nuclear lamin ${ }^{26}$. 


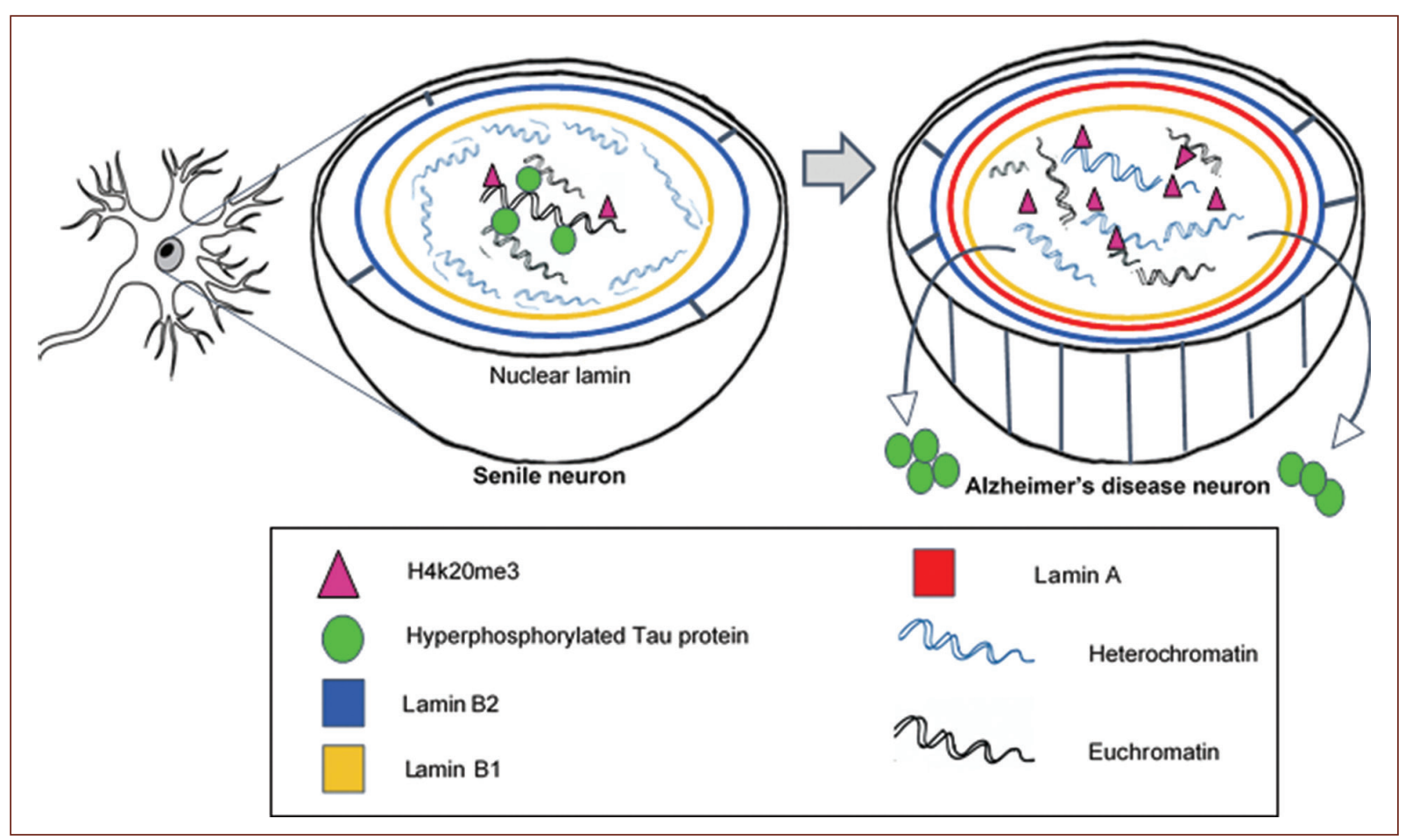

Figure 3. Nuclear hypothesis of Alzheimer's disease (AD) pathogenesis. Senile neurons initiate DNA repair by entering the cell cycle, but the complexity of their nucleus-cytoskeleton prevents neurons from dividing and they gradually die. $A D$ neurons survive by triggering an aberrant structural and functional transformation of the nucleus, consisting in lamin A expression and Tau protein transfer to the cytoplasm. Neurofibrillary tangles are consequence of the attempted neuronal repair, and the loss of the protector role of nuclear Tau results in global chromatin disorganization.

Our work demonstrated that lamin B1 is expressed in the nuclear membrane both in young subjects and in $A D^{26}$. As for lamin $B 2$, it is expressed in healthy, senile, and $A D$ subjects; however, there is an exciting change in its expression. In adult subjects, it has perinuclear expression, but it begins to move to the nucleoplasm in senile subjects, giving rise to two different neuronal populations ${ }^{37}$. Both the striking findings of the presence of lamin $A$ and the expression changes in lamin B2 raised numerous questions about the impact that nuclear lamin modifications have on the pathogenesis of AD.

\section{Nuclear hypothesis of AD pathogenesis}

The comparison of lamins A and B2 expression and of Tau protein in hippocampal neurons of senile and $A D$ subjects suggests a completely new and fascinating theory about the pathogenesis of $A D$.

Previously, it was known that at early AD stages, two different neuronal populations coexist, one group enters an abortive cell cycle and represents $75-90 \%$ of neuronal loss ${ }^{38-40}$. A second group of neurons does not die but they suffer a transformation of nucleus and cytoskeleton, which triggers hyperphosphorylation and aggregation of Tau.

From our research work, as well as from the great contribution of previous studies, we arrived to the following hypothesis. The expression of lamin B2 in the nucleoplasm indicates that the neurons entered the G1 phase, which coincides with the fact that this expression is observed in healthy senile adults; therefore, we can deduce that the neuron is beginning its effort to repair its DNA, which bears aging associated DNA damage. To survive, post-mitotic neurons generate a change in the nuclear lamin by inducing abnormal expression of lamin $A$ in the inner part of the nuclear lamin and increasing Lamin B2 expression in the nuclear periphery. This restructuration of their nucleus and cytoskeleton increases the rigidity of the nucleus and the degree of viscosity of the chromatin ${ }^{41}$. The presence of lamin $A$ is the critical difference between senile neurons and $A D$ neurons. In turn, this abnormal expression of lamin $A$ leads to the upregulation of the epigenetic marker H420me3, whose physiological function is to silence perinuclear heterochromatin blocks (Fig. 3). 
Although this tremendous effort to protect the genome is ultimately unsuccessful, since neurons are left cycling in the G2-M phase from where they cannot escape, the loss of neuronal plasticity and synaptic dysfunction is the price that the damaged neuron pays surviving a few years, delaying the inevitable neuronal death $^{26}$ (Fig. 3).

\section{Perspectives}

The above described chain of molecular events provides also an explanation for the lack of success of current $A D$ treatments. Since therapies are targeting molecular $A D$ hallmarks such $A \beta$ plaques and tau hyperphosphorylation, the early nuclear damage and $a b$ errant cell cycle activation underlying the proteinopathy are ignored. In light of this novel pathophysiological mechanism, drugs that could interfere with the cell cycle machinery are candidates for AD management. In this respect, drugs currently used in cancer therapy by targeting cell cycle progression and mitosis are currently tested in animal models of $A D^{42}$.

Experimental tools against oxidative damage and mitochondrial dysfunction underlying DNA damage are ongoing. However, these treatments are still undergoing clinical trials and many of them have not achieved satisfactory results. It is worth considering that lifestyle and nutritional intervention may be effective primary prevention strategies for $A D$, since they could reduce the DNA damage accumulation that results in cell cycle activation. Some proposed modifications are healthy nutritive food components, rich in their antioxidant and anti-inflammatory properties; intermittent fasting, which is effective in brain aging by improving metabolic health, and physical activity which reduces mitochondrial dysfunction by activating various transcription factors in bioenergetics processes ${ }^{43}$.

\section{Conclusion}

Cell cycle reentry by post-mitotic hippocampal neurons is a biological mechanism to restore nuclear-cellular homeostasis after accumulation of DNA damage. Aging presents a state of massive DNA damage that does not allow to restore homeostasis. For this reason, post-mitotic neurons make an immense effort to survive or to delay their death, sacrificing important neuronal functions. This survival success is evidenced by the presence of lamin $A$ and the exit of the Tau protein from the nucleus. Nevertheless, AD neurons manage to survive for years, and even decades, with a progressive deterioration of synaptic functionality that leads inevitably to dementia.

\section{Funding}

This work was supported by project 1.010.924. Fundación Alfonso X el Sabio-Banco Santander, Spain.

\section{Conflicts of interest}

None.

\section{Ethical disclosures}

Protection of human and animal subjects. The authors declare that no experiments were performed on humans or animals for this study.

Confidentiality of data. The authors declare that no patient data appear in this article.

Right to privacy and informed consent. The authors declare that no patient data appear in this article.

\section{References}

1. Dementia. World Health Organization; 2020. Available from: http://www. who.int/news-room/fact-sheets/detail/dementia.

2. Reyna Carrizales M, González Rubio M, López Esqueda F, González González G. Demencias, Una Visión Panorámica. V Simposio de Medicina Geriátrica. San Luis Potosí: Editorial Universitaria Potosina; 2014.

3. McKhann G, Knopman D, Chertkow H, Hyman B, Jack C, Kawas C, et al. The diagnosis of dementia due to Alzheimer's disease: Recommendations from the National Institute on Aging-Alzheimer's Association Workgroups on diagnostic guidelines for Alzheimer's disease. Alzheimers Dement 2011;7:263-9.

4. Janelidze S, Berron D, Smith R, Strandberg O, Proctor NK, Dage JL, et al. Associations of plasma phospho-tau217 levels with tau positron emission tomography in early Alzheimer disease. JAMA Neurol. 2020;2020:e204201.

5. Rodríguez-Leyva I, Chi-Ahumada E, Calderón-Garcidueñas A, Medina-Mier V, Santoyo ME, Martel-Gallegos G, et al. Presence of phosphorylated Tau protein in the skin of Alzheimer's disease patients. J Mol Biomarkers Diagn. 2015;S6:005.

6. Arredondo LF, Aranda-Romo S, Rodriguez-Leyva I, Chi-Ahumada E, Saikaly SK, Portales-Perez DP, et al. Tau protein in oral mucosa and cognitive state: a cross-sectional study. Front. Neurology. 2017:8:554.

7. Cass SP. Alzheimer's disease and exercise: a literature review. Curr Sports Med Rep. 2017;16:19-22.

8. Hardy JA, Higgins GA. Alzheimer's disease: the amyloid cascade hypothesis. Science. 1992:256:184-5.

9. Ballard C, Gauthier S, Corbett A, Brayne C, Aarsland D, Jones E. Alzheimer's disease. Lancet. 2011;377:1019-31.

10. Cordone S, Annarumma L, Rossini PM, De Gennaro L. Sleep and $\beta$-amyloid deposition in Alzheimer disease: insights on mechanisms and possible innovative treatments. Front Pharmacol. 2019;10:695.

11. Harrington KD, Lim YY, Ames D, Hassenstab J, Laws SM, Martins RN, et al. Amyloid $\beta$-associated cognitive decline in the absence of clinical disease progression and systemic illness. Alzheimers Dement (Amst). 2017;8:156-64.

12. Morris JC, Roe CM, Grant EA, Head D, Storandt M, Goate AM, et al. Pittsburgh compound $B$ imaging and prediction of progression from cognitive normality to symptomatic Alzheimer disease. Arch. Neurol. 2019;66:1469-75.

13. Arriagada PV, Growdon JH, Hedley-Whyte EH, Hyman BT. Neurofibrillary tangles but not senile plaques parallel duration and severity of Alzheimer's disease. Neurology. 1992;42:631-9.

14. Orr M, Sullivan A, Frost B. A brief overview of tauopathy: causes, consequences, and therapeutic strategies. Trends Pharmacol Sci. 2017;38:637-48.

15. Goedert M, Spillantini MG. Propagation of Tau aggregates. Mol Brain. 2017; $10: 18$ 
16. Dujardin S, Lécolle K, Caillierez R, Bégard S, Zommer N, Lachaud C, et al. Neuron-to-neuron wild-type Tau protein transfer through a trans-synaptic mechanism: relevance to sporadic tauopathies. Acta Neuropatho Commun. 2014;2:14.

17. Nagy Z, Esiri MM, Smith AD. Expression of cell division markers in the hippocampus in Alzheimer's disease and other neurodegenerative conditions. Acta Neuropathol. 1997;93:294-300.

18. Arendt $T$, Brückner MK, Mosch B, Lösche A. Selective cell death of hyperploid neurons in Alzheimer's disease. Am J Pathol. 2010;177:15-20.

19. Feser J, Tyler J. Chromatin structure as a mediator of aging. FEBS Lett. 2011;585:2041-8.

20. Hou Y, Dan X, Babbar M. Ageing as a risk factor for neurodegenerative disease. Nat Rev Neurol. 2019;15:565-81.

21. Sultan A, Nesslany F, Violet M. Nuclear tau, a key player in neurona DNA protection. J Biol Chem. 2011;286:4566-75.

22. Gil L, Federico C, Pinedo F. Aging dependent effect of nuclear Tau. Brain Res. 2017;1677:129-37.

23. Sjöberg MK, Shestakova E, Mansuroglu Z. Tau protein binds to pericentromeric DNA: a putative role for nuclear Tau in nucleolar organization. J Cell Sci. 2006;119:2025-34.

24. Federico C, Gil L, Bruno F, D'Amico AG. Phosphorylated nucleolar Tau protein is related to the neuronal in vitro differentiation. Gene. 2018:664:1-11.

25. Meier S, Bell M, Lyons DN. Pathological Tau promotes neuronal damage by impairing ribosomal function and decreasing protein synthesis. J Neurosci. 2016;36:1001-7.

26. Gil L, Niño SA, Chi-Ahumada E. Perinuclear lamin A and nucleoplasmic lamin b2 characterize two types of hippocampal neurons through Alzheimer's disease progression. Int J Mol Sci. 2020;21:1841.

27. Frost B, Hemberg M, Lewis J, Feany MB. Tau promotes neurodegeneration through global chromatin relaxation. Nat Neurosci. 2014;17:357-66.

28. Mansuroglu Z, Benelli-Mokrani H, Marcato V. Loss of Tau protein affects the structure, transcription and repair of neuronal pericentromeric heterochromatin. Sci Rep. 2016;6:33047.

29. Benelli-Mokrani H, Mansuroglu Z, Chauderlier A. Genome-wide identification of genic and intergenic neuronal DNA regions bound by Tau protein under physiological and stress conditions. Nucleic Acids Res. 2018;46:11405-22.

30. Eftekharzadeh B, Daigle JG, Kapinos LE. Tau protein disrupts nucleocytoplasmic transport in Alzheimer's disease. Neuron. 2018:99:925-40.e7.
31. Hsieh YC, Guo C, Yalamanchili HK. Tau-mediated disruption of the spliceosome triggers cryptic RNA splicing and neurodegeneration in Alzheimer's disease. Cell Rep. 2019;29:301-16.e10.

32. Frost B. Alzheimer's disease: an acquired neurodegenerative laminopathy. Curr Biol. 2016;26:129-36.

33. Nmezi B, Xu J, Fu R. Concentric organization of A-and B-type lamins predicts their distinct roles in the spatial organization and stability of the nuclear lamin. Proc Natl Acad Sci U S A. 2019;116:4307-15.

34. Islam MI, Hossain MS, Park IS. Differential involvement of caspase-6 in amyloid- $\beta$-induced fragmentation of lamin A and B. Biochem Biophys Rep. 2020;4:100839.

35. Simon DN, Wilson KL. The nucleoskeleton as a genome-associated dynamic' network of networks. Nat Rev Mol Cell Biol. 2011;12:695-708.

36. Cho S, Vashisth M, Abbas A. Mechanosensing by the lamin protects against nuclear rupture, DNA damage, and cell-cycle arrest. Dev Cell. 2019;49:920-35.e5.

37. Lammerding J, Fong LG, Ji JY. Lamins $A$ and $C$ but not lamin B1 regulate nuclear mechanics. J Biol Chem. 2006;281:25768-80.

38. Lopes JP, Blurton-Jones M, Yamasaki TR, Agostinho P, LaFerla FM. Activation of cell cycle proteins in transgenic mice in response to neuronal loss but not amyloid-beta and tau pathology. J Alzheimers Dis. 2009; 16:541-9.

39. Lippa CF, Halmos JE, Pulaski-Salo D, DeGennaro LJ, Drachman DA Alzheimer's disease and aging: effects on perforant pathway perikarya and synapses. Neurobiol Aging. 1992;13:405-11.

40. Fukutani Y, Kobayashi K, Nakamura I, Watanabe K, Isaki K, Cairns NJ. Neurons, intracellular and extracellular neurofibrillary tangles in subdivisions of the hippocampal cortex in normal aging and Alzheimer's disease. Neurosci Lett. 1995;200:57-60.

41. Winter O, Hirsch-Attas N, Schlossberg M. A unified linear viscoelastic model of the cell nucleus defines the mechanical contributions of lamins and chromatin. Adv Sci (Weigh). 2020;7:1901222.

42. Rao CV, Asch AS, Carr DJ, Yamada HY. Amyloid-beta accumulation cycle as a prevention and/or therapy target for Alzheimer's disease. Aging Cell. 2020;19:e13109.

43. de Cabo R, Mattson MP. Effects of intermittent fasting on health, aging, and disease. N Engl J Med. 2019;381:2541-51. 